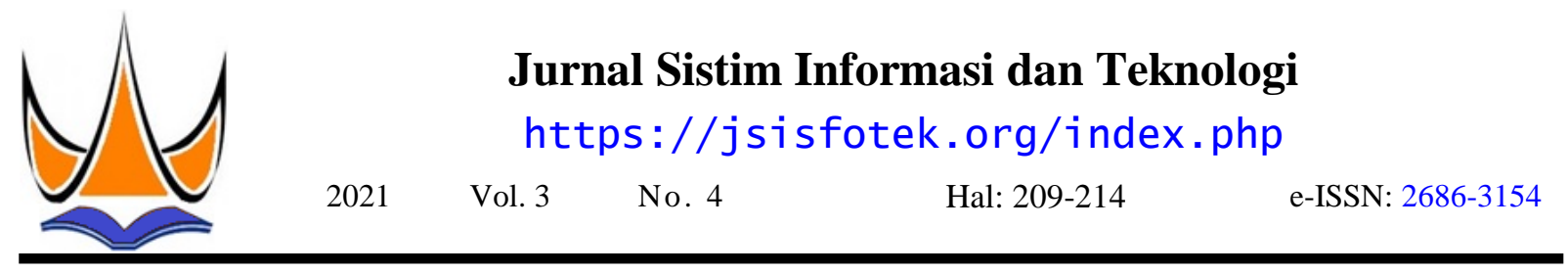

\title{
Sistem Pakar Menggunakan Metode Certainty Factor dalam Menganalisis Penyakit Karies Gigi pada Manusia
}

\author{
Fajri Ilhami Andrean ${ }^{1 凶}$, Yuhandri Yunus ${ }^{2}$ \\ ${ }^{1}$ Independent Researcher \\ ${ }^{2}$ Universitas Putra Indonesia YPTK Padang \\ the1itt1ei1ham@gmai1.com
}

\begin{abstract}
Caries is a dental disease that is often found, which is a disease of the hard tissues of the teeth in the form of continuous loss of mineral ions on the surface of tooth enamel, which is mostly caused by bacterial metabolism. A low level of awareness in caring for teeth causes a bad impact on dental health and on body health. At present time, people generally do not have knowledge of analyzing dental caries disease, which can later cause severe damage to teeth, such as the death of the dental pulp. This study aims to analyze caries disease using the Certainty Factor method. In this study, 50 data sets were processed, obtained from interviews with experts at the Rahmatan Lil Alamin Clinic, Padang, Indonesia. They found several factors that cause dental caries disease in humans. The data was obtained from the medical records of patients who had undergone an examination at the clinic. The data is used to analyze the type of caries disease based on the guidance of the expert. The processing steps carried out are solving the rule, determining the weight value of each symptom and calculating the Certainty Factor value. The results obtained after testing this method show that there are $94 \%$ of people who suffer from caries disease, the type most often suffered by patients with superficial caries. The test results can analyze caries disease specifically, thus the expert system used can be recommended to help dentists analyze dental caries disease in humans.
\end{abstract}

Keywords: Dental Karies, Analisys, Expert System, Certainty Factor Method, Dental Health.

\begin{abstract}
Abstrak
Karies adalah penyakit gigi yang kerap ditemukan, yaitu suatu penyakit pada jaringan keras gigi berupa hilangnya ion - ion mineral secara terus menerus pada permukaan enamel gigi yang sebagian besar disebabkan oleh metabolisme bakteri. Tingkat kesadaran yang rendah dalam merawat gigi menyebabkan dampak buruk pada kesehatan gigi dan terhadap kesehatan tubuh. Pada saat sekarang ini umumnya masyarakat belum memiliki pengetahuan dalam menganalisis tentang penyakit karies gigi yang nantinya dapat mengakibatkan kerusakan yang parah terhadap gigi seperti matinya pulpa gigi. Penelitian ini bertujuan untuk menganalisis penyakit karies dengan menggunakan metode Certainty Factor. Dalam penelitian ini diolah data sebanyak 50 data yang diperoleh dari hasil wawancara dengan pakar pada Klinik Rahmatan Lil Alamin Padang Indonesia. Ditemukan beberapa faktor yang menyebabkan penyakit karies gigi pada manusia. Data tersebut diperoleh dari catatan medis pasien yang telah melakukan pemeriksaan di klinik. Data tersebut digunakan untuk menganalisis jenis penyakit karies berdasarkan bimbingan dari pakar tersebut. Tahapan pengolahan yang dilakukan adalah pemecahan rule, menentukan nilai bobot setiap gejala dan menghitung nilai Certainty Factor. Hasil yang didapatkan setelah dilakukan pengujian terhadap metode ini adalah terdapat $94 \%$ yang mengidap penyakit karies dengan jenis yang paling sering diderita pasien karies superfisialis. Hasil pengujian dapat menganalisis penyakit karies secara spesifik, dengan demikian sistem pakar yang digunakan telah dapat direkomendasikan untuk membantu dokter gigi menganalisis penyakit karies gigi pada manusia.
\end{abstract}

Kata kunci: Karies Gigi, Analisis, Sistem Pakar, Certainty Factor, Kesehatan Gigi.

(C) 2021 JSisfotek

\section{Pendahuluan}

Sistem Pakar bisa diartikan sebagai sistem yang dapat membantu dalam menuntun seseorang menyelesaikan masalah dengan menggabungkan pengetahuan base dengan mesin inferensi yang dapat meniru cara kerja dari seorang pakar. Pengetahuan pakar yang terdapat dalam database Sistem Pakar dapat dimanfaatkan sebagai landasan dalam menyelesaikan masalah yang sering terjadi. Sistem Pakar adalah sebuah sistem yang dibangun pada komputer dengan cara menirukan proses pemikiran pakar yang memiliki pengetahuan untuk mengatasi masalah tertentu yang umumnya memerlukan keahlian seorang pakar [1].
Penelitian terdahulu Sistem Pakar dimanfaatkan dalam hal mengidentifikasi penyakit gingivitis. Gingivitis merupakan penyakit radang gigi yang berasal dari bakteri yang berkembang di dalam mulut yang mengakibatkan rusaknya sel - sel jaringan penghubung yang terdapat dalam gigi. Maka dalam penelitian ini dilakukan pengolahan data dengan memilih menerapkan metode certainty factor (CF). Hasil yang didapatkan dari pengujian terhadap metode certainty factor ini adalah terdapat $96 \%$ pasien yang mengidap penyakit gingivitis, dengan jenis yang paling sering diderita pasien adalah gingivitis marginal [2].

Penelitian terdahulu Sistem Pakar juga digunakan dalam menganalisis penyakit hepatitis. Hepatitis adalah 
salah satu penyakit menular dengan jumlah pasien yang Karies merupakan salah satu penyakit gigi yang kerap cukup banyak. Pada umunya hepatitis dapat dideteksi ditemukan, yaitu suatu penyakit pada jaringan keras hanya dengan mengunjungi dokter, namun hal ini gigi berupa hilangnya ion - ion mineral secara terus biasanya hanya dilakukan pada kalangan mengengah ke menerus pada permukaan enamel gigi yang sebagian atas. Bagi kalangan menengah ke bawah alasan besar disebabkan oleh metabolisme bakteri [7]. financial dan ketidaktahuan tentang hepatitis Penyakit karies gigi pada umumnya akan diderita oleh menjadikan masyarakat untuk tidak mengunjungi orang yang jarang melakukan perawatan gigi atau dokter untuk pemeriksa kesehatan. Maka dari itu, membiarkan kotoran pada gigi tetap menempel pada penelitian ini menggunakan metode certainty factor gigi. Rendahnya tingkat pengetahuan tentang penyakit untuk pengolahan datanya. Metode ini memungkinkan gigi ini nantinya akan berakibat pada kerusakan yang suatu kesimpulan atau diagnosis, meskipun ada parah terhadap gigi [8].

ketidakpastian kondisi pasien atau ketidakpastian aturan yang digunakan untuk mendapatkan kesimpulan. Hasilnya menunjukkan bahwa tingkat kesalahan dalam proses diagnosis berada di bawah $36 \%$ [3].

Metode certainty factor merupakan salah satu metode dari mesin inferensi yang digunakan dalam hal menggambarkan tingkat kenyakinan seorang pakar pada masalah yang cukup banyak dijumpai serta Sistem Pakar juga dapat diterapkan dalam mendeteksi membantu dalam pengambilan keputusan atau kerusakan keyboard. Keyboard adalah alat musik tekan kesimpulan dari beberapa kaidah yang telah dibentuk yang menghasilkan suara untuk beberapa jenis nada [9]. Kombinasi yang ada pada certainty factor dapat dan suara. Kerusakan akan berdampak pada kualitas digunakan untuk mengambil dua kesimpulan hipotesis suara, oleh karena itu untuk memainkan dan melakukan dari suatu kasus [10]. Berdasarkan uraian keseluruhan perawatan keyboard dibutuhkan pengetahuan khusus yang disebutkan di atas maka penulis akan melakukan tentang keyboard. Sistem Pakar ini digunakan untuk penelitian dengan judul yaitu Sistem Pakar membantu orang yang tidak mengerti keyboard agar Menggunakan Metode Certainty Factor dalam dapat menganalisis, mengidentifikasi dan memperbaiki Menganalisis Penyakit Karies Gigi pada Manusia.

kerusakan keyboard berdasarkan fakta - fakta yang ada yang kemudian disusun untuk dijadikan sebuah rule untuk menemukan solusi memperbaiki kerusakan 2.1. Subjek Penelitian

keyboard [4].

\section{Metodologi Penelitian}

Penerapan Sistem Pakar menggunakan metode $\begin{aligned} & \text { Subjek yang ada pada penelitian ini adalah } \\ & \text { implementasi sistem pakar untuk menganalisis penyakit }\end{aligned}$ certainty factor lumayan banyak digunakan dalam karies gigi pada manusia dengan memanfaatkan menyelesaikan banyak masalah di berbagai bidang Certainty Factor sebagai metode yang digunakan. kehidupan. Salah satunya masalah pada bidang Masalah yang terdapa pada penlitian ini adalah kecantikan seperti Sistem Pakar untuk mengidentifikasi kurangnya pengetahuan masyarakat dalam jenis kulit wajah dengan metode certainty factor. menganalisis penyakit karies sehingga bisa Didapatkan hasil penilaian sistem oleh responden menyebabkan kerusakan yang lebih parah pada gigi menyatakan bahwa $91 \%$ dari sistem sangat mudah jika selalu dibiarkan. untuk digunakan [5].

Di Indonesia, penyakit gigi telah menjadi salah satu masalah yang cukup banyak dijumpai dan kerap menjadi gangguan dalam melakukan aktivitas harian. Menurut data Riset Kesehatan Dasar (Riskesdas) tahun 2007 dan 2013 berubah dari 23,2\% meningkat menjadi $25,9 \%$. Sebab permasalahan tersebut persentase penduduk yang memperoleh perawatan medis berubah dari $29,7 \%$ tahun 2007 meningkat menjadi $31,1 \%$ pada tahun 2013. Penanganan yang terlambat menyebabkan kondisi gigi yang sakit menjadi lebih parah. Ada beberapa faktor yang menyebabkan timbulnya gangguan gigi dan mulut yakni rendahnya tingkat kesadaran masyarakat dalam menjaga kesehatan rongga mulut. Faktor yang menjadi penyebab tidak teraturnya pemeriksaan kepada dokter gigi adalah jarangnya diperhatikan kesehatan gigi dan mulut, konsultasi yang memerlukan biaya untuk melakukannya, dan antrean yang panjang adalah penyebab masyarakat jarang melakukan konsultasi [6].

\subsection{Sistem Pakar}

Sistem Pakar adalah bagian dari artificial intelligence yang membuat komputer menyimpulkan pengetahuan pakar domain. Sistem Pakar dikembangkan dengan meniru pemikiran pakar. Sistem Pakar sebagai suatu program komputer yang cerdas dalam memanfaatkan pengetahuan dan kesimpulan penalaran untuk memecahkan suatu persoalan yang cukup rumit, sehingga dibutuhkan seorang pakar untuk menangani masalah tersebut [11].

\subsection{Metode Certainty Factor}

Metode Certainty Factor digunakan untuk menghadapi permasalahan yang tidak memiliki jawaban pasti. Ketidakpastian bisa menjadi probabilitas. Certainty Factor adalah teknik yang digunakan dalam pembuktian sebuah fakta pasti atau tidak pasti dalam bentuk metrik yang biasa dimanfaatkan sebuah Sistem Pakar. Namun dalam faktor kepastian, setiap aturan memiliki nilai bukan hanya premis. Faktor kepastian 
menunjukkan ukuran yang sesuai dari fakta atau aturan [12].

Pengolahan data dengan metode Certainty Factor dibutuhkan Tabel 1 uncertainty term yang dimanfaatkan untuk interpretasi "term" dari pakar ke dalam nilai IL.

Tabel 1. Tabel Nilai Certainty Factor

\begin{tabular}{rlr}
\hline No & Uncertainty Term & Nilai CF \\
\hline 1. & Tidak & 0 \\
2. & Tidak Tahu & 0.2 \\
3. & Sedikit Yakin & 0.4 \\
4. & Cukup Yakin & 0.6 \\
5. & Yakin & 0.8 \\
6. & Sangat Yakin & 1 \\
\hline
\end{tabular}

Rumus yang biasa digunakan dalam pencarian nilai Certainty Factor dibuatkan pada Persamaan (1).

$$
\text { IL }[W, z]=\operatorname{Min}(\mathbb{I L}(\mathrm{R}, \mathrm{z})) \times \mathbb{I L}(\mathrm{W}, \mathrm{R})
$$

Dimana IL adalah nilai Certainty Factor, IL(R,z) adalah Certainty Factor evidence $\mathrm{E}$ yang dipengaruhi evidence z, IL(W,R) adalah Certainty Factor jawaban yang diketahui evidence diketahui dengan pasti, IL(W,z) adalah Certainty Factor jawaban yang terpengaruh oleh evidence $\mathrm{z}, \mathrm{z}$ adalah fakta dan $\mathrm{W}$ adalah hipotesis.

Jika ditemukan kaidah yang memiliki kesimpulan yang sama atau memiliki beberapa gejala, maka rumus IL yang digunakan adalah yang disajikan pada Persamaan (2).

$\mathrm{IL}_{\text {combine }}=\mathbb{L}_{\text {old }}+\mathbb{I}_{\text {qeiala }} \times\left(1-\mathbb{I}_{\text {old }}\right)$

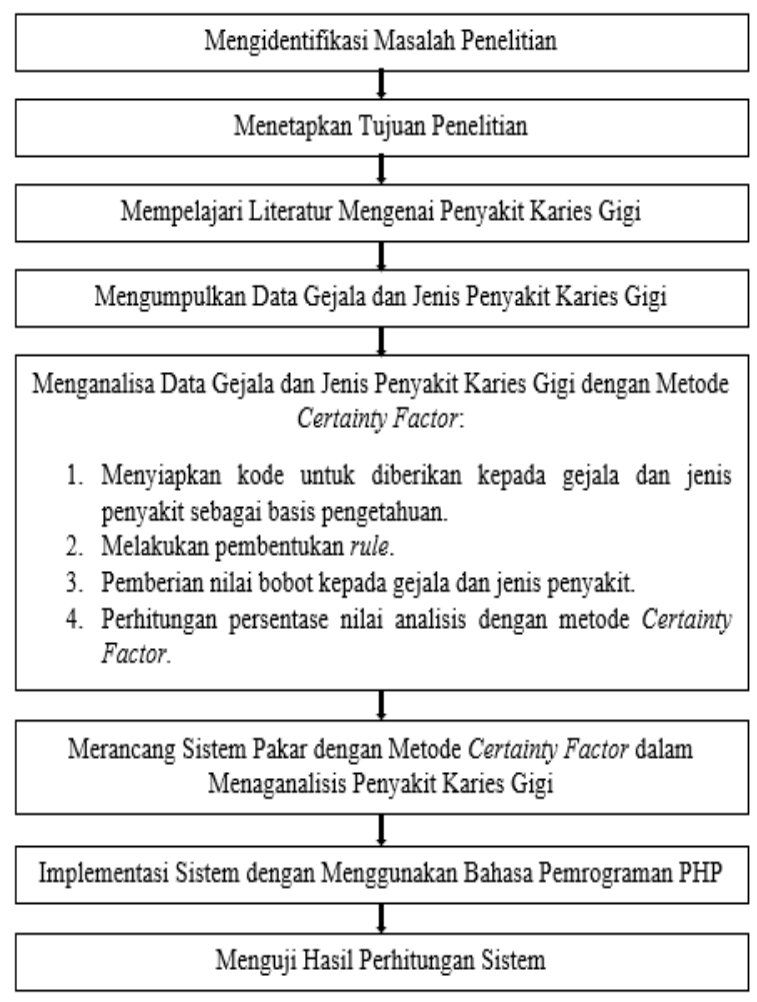

Gambar 1. Kerangka Kerja Penelitian

Kerangka kerja merupakan penggambaran terperinci yang didasari dengan cara yang terorganisir sehingga penelitian dapat mencapai tujuannya dan memilki penilaian yang semestinya.

Dimana $\mathrm{IL}_{\text {combine }}$ adalah nilai Certainty Factor 3. Hasil dan Pembahasan gabungan, $\mathrm{IL}_{\text {old }}$ adalah nilai Certanty Faktor yang digunakan pertama, dan $\mathrm{IL}_{\text {Gejala }}$ adalah nilai Certainty Factor yang digunakan kedua.

\subsection{Metode Pengumpulan Data}

\subsection{Analisi Data}

Data yang dibutuhkan untuk penelitian ini merupakan data jenis penyakit karies, gejala dari karies, penanggulangan sera data pasien yang digunakan untuk Pengumpulan data yang dilakukan dalam melakukan pengujian sistem pakar ini, data-data ini didapatkan penelitian ini menggunakan dua metode yakni studi dari hasil wawancara yang telah dilakukan dengan pustaka (membaca buku dan referenssi lainnya) yang pakar.

berkaitan dengan penelitian dan melakukan wawancara dengan pakar yang relevan pada objek penelitian. Wawancara yang dilakukan adalah wawancara lansung ke tempat praktek pakar yang juga menjadi objek dalam penelitian ini.

\subsection{Kerangka Kerja}

Kerangka kerja dalam suatu penelitian dibutuhkan agar setiap tahapan penelitian dapat diselesaikan dengan tepat. Disajikan kerangka kerja yang dapat dilihat pada Gambar 1.

Tabel 2. Tabel Jenis Penyakit Karies

\begin{tabular}{ccc}
\hline No & Kode Penyakit & Jenis Penyakit \\
\hline 1. & P01 & Karies Superfisialis \\
2. & P02 & Karies Media \\
3. & P03 & Karies Profunda \\
\hline
\end{tabular}

Didapatkan 3 jenis penyakit karies yang umum diderita masyarakat, setiap jenis penyakit tersebut ditandai dengan kode penyakit dari kode P01 sampai P03 yang bisa dilihat pada Tabel 2. Data berikutnya merupakan data gejala dari penyakit karies yang diperoleh dari pakar pada objek dalam penelitian. 
Tabel 3. Tabel Data Gejala

\begin{tabular}{ccl}
\hline No & $\begin{array}{c}\text { Kode } \\
\text { Gejala }\end{array}$ & Nama Gejala \\
\hline 1. & G01 & Gigi berlubang \\
2. & G02 & Adanya lubang (ukuran 1-2 mm) \\
3. & G03 & Adanya lubang (ukuran 3-5 mm) \\
4. & G04 & Adanya lubang (masuk 2 butir nasi) \\
5. & G05 & Nyeri ketika ada ransangan \\
6. & G06 & Tidak sakit pada saat diketuk \\
7. & G07 & Adanya lubang hitam dipermukaan gigi \\
8. & G08 & Nyeri secara spontan \\
9. & G09 & Sakit saat diketuk \\
10. & G10 & Pembusukkan dalam lubang \\
11. & G11 & Ada lubang bewarna coklat \\
12. & G12 & Terjadi pembengkakkan gusi \\
13. & G13 & Hancurnya lapisan dentin \\
14. & G14 & Gigi ngilu berdenyut - denyut \\
\hline
\end{tabular}

Diperoleh 14 gejala dimana gejala-gejala tersebut yang menjadi penyebab dari 3 jenis penyakit karies gigi yang telah dibuat pada tabel 2. Setiap jenis gejala diberi kode dari G01 sampai dengan G14 yang telah dipaparkan pada Table 3 . Berikutnya adalah pembuatan rule dan memberikan nilai IL dari pakar.

Tabel 4. Tabel Rule dan Nilai IL

\begin{tabular}{ccc}
\hline No & \multicolumn{1}{c}{ Rule } & Nilai IL \\
\hline 1. & IF G01 AND G02 AND G05 THEN P01 & 0.6 \\
2. & IF G02 AND G06 AND G07 THEN P01 & 1.0 \\
3. & IF G01 AND G08 AND G11 THEN P02 & 0.8 \\
4. & IF G03 AND G09 AND G10 THEN P02 & 1.0 \\
5. & IF G04 AND G12 AND G14 THEN P03 & 0.8 \\
6. & IF G04 AND G08 AND G13 THEN P03 & 1.0 \\
\hline
\end{tabular}

Setelah dilakukan proses pembentukan rule dan memberikan nilai IL oleh pakar, maka dilakukan proses pencarian metode Certainty Faktor dengan dilakukan pencarian nilai IL yang ada pada data 3 pasien yang disajikan pada Tabel 5.

Tabel 5. Tabel Pemberian nilai IL Pasien

\begin{tabular}{lllc}
\hline Pasien & Kode Gejala & Tingkat Kenyakinan & Nilai CF \\
\hline \multirow{3}{*}{ Pasien 1 } & G01 & Cukup Yakin & 0.6 \\
& G02 & Yakin & 0.8 \\
Pasien 2 & G01 & Yakin & 0.8 \\
& G08 & Cukup Yakin & 0.6 \\
& G11 & Sangat Yakin & 1.0 \\
& G05 & Sangat Yakin & 1.0 \\
& G02 & Cukup Yakin & 0.6 \\
& G06 & Yakin & 0.8 \\
& G07 & Cukup Yakin & 0.6 \\
& G01 & Sangat Yakin & 1.0 \\
\hline
\end{tabular}

\subsection{Validasi}

Penelitian ini dimanfaatkan untuk menganalisis penyakit karies gigi pada manusia. Data yang digunakan 50 sample yang diuji. Tingkat akurasi yang diperoleh pada sistem dapat dicari dengan menggunakan Persamaan (3):

Tingkat Akurasi $=\frac{\text { Jumlah data benar }}{\text { Jumlah data uji }} \times 100 \%$

\section{(3) 3.3. Hasil}

Hasil validasi yang dilakukan terhadap 50 sample data disajikan pada Tabel 6.
Tabel 6. Tabel Validasi Data

\begin{tabular}{|c|c|c|}
\hline No & Pasien & Hasil Validasi \\
\hline 1. & Pasien 1 & Valid \\
\hline 2. & Pasien 2 & Valid \\
\hline 3. & Pasien 3 & Valid \\
\hline 4. & Pasien 4 & Valid \\
\hline 5. & Pasien 5 & Valid \\
\hline 6. & Pasien 6 & Valid \\
\hline 7. & Pasien 7 & Valid \\
\hline 8. & Pasien 8 & Valid \\
\hline 9. & Pasien 9 & Valid \\
\hline 10. & Pasien 10 & Valid \\
\hline 11. & Pasien 11 & Valid \\
\hline 12. & Pasien 12 & Tidak Valid \\
\hline 13. & Pasien 13 & Valid \\
\hline 14. & Pasien 14 & Valid \\
\hline 15. & Pasien 15 & Valid \\
\hline 16. & Pasien 16 & Tidak Valid \\
\hline 17. & Pasien 17 & Valid \\
\hline 18. & Pasien 18 & Valid \\
\hline 19. & Pasien 19 & Valid \\
\hline 20. & Pasien 20 & Valid \\
\hline 21. & Pasien 21 & Valid \\
\hline 22. & Pasien 22 & Valid \\
\hline 23. & Pasien 23 & Valid \\
\hline 24. & Pasien 24 & Valid \\
\hline 25. & Pasien 25 & Valid \\
\hline 26. & Pasien 26 & Valid \\
\hline 27. & Pasien 27 & Valid \\
\hline 28. & Pasien 28 & Tidak Valid \\
\hline 29. & Pasien 29 & Valid \\
\hline 30. & Pasien 30 & Valid \\
\hline 31. & Pasien 31 & Valid \\
\hline 32. & Pasien 32 & Valid \\
\hline 33. & Pasien 33 & Valid \\
\hline 34. & Pasien 34 & Valid \\
\hline 35. & Pasien 35 & Valid \\
\hline 36. & Pasien 36 & Valid \\
\hline 37. & Pasien 37 & Valid \\
\hline 38. & Pasien 38 & Valid \\
\hline 39. & Pasien 39 & Valid \\
\hline 40. & Pasien 40 & Valid \\
\hline 41. & Pasien 41 & Valid \\
\hline 42. & Pasien 42 & Valid \\
\hline 43. & Pasien 43 & Valid \\
\hline 44. & Pasien 44 & Valid \\
\hline 45. & Pasien 45 & Valid \\
\hline 46. & Pasien 46 & Valid \\
\hline 47. & Pasien 47 & Valid \\
\hline 48. & Pasien 48 & Valid \\
\hline 49. & Pasien 49 & Valid \\
\hline 50. & Pasien 50 & Valid \\
\hline
\end{tabular}

Tingkat Akurasi $=\frac{47}{50} \times 100 \%=94 \%$

Denga menggunakan persamaan 3 didapatkan tingkat akurasi Sistem Pakar menganalisis penyakit karies gigi pada manusia sebesar $94 \%$ dengan menggunakan metode Certainty Factor.

Berdasarkan hasil pengolahan 10 contoh data dengan mengimplementasikan metode Certainty Factor, maka disajikan hasil pengolahan pada Tabel 7: 
Tabel 7. Tabel Pengolahan 10 Data Pasien

\begin{tabular}{cclr}
\hline Nama & \multicolumn{1}{c}{ Kode } \\
Pasien & Penyakit & \multicolumn{1}{c}{ Nama Penyakit } & Nilai CF \\
\hline Pasien 01 & P01 & Karies Superfisialis & $36 \%$ \\
Pasien 02 & P02 & Karies Media & $48 \%$ \\
Pasien 03 & P01 & Karies Superfisialis & $74 \%$ \\
Pasien 04 & P01 & Karies Superfisialis & $40 \%$ \\
Pasien 05 & P03 & Karies Profunda & $32 \%$ \\
Pasien 06 & P01 & Karies Superfisialis & $24 \%$ \\
Pasien 07 & P01 & Karies Superfisialis & $60 \%$ \\
Pasien 08 & P01 & Karies Superfisialis & $12 \%$ \\
Pasien 09 & P01 & Karies Superfisialis & $24 \%$ \\
Pasien 10 & P02 & Karies Media & $59 \%$ \\
\hline
\end{tabular}

Hasil dari Sistem Pakar bisa diakses dengan menggunkaan perangkat lunak yakni web browser. Dimana tampilan Sistem Pakar dalam menganalisis penyakit karies gigi pada manusia disajikan pada Gambar 2:

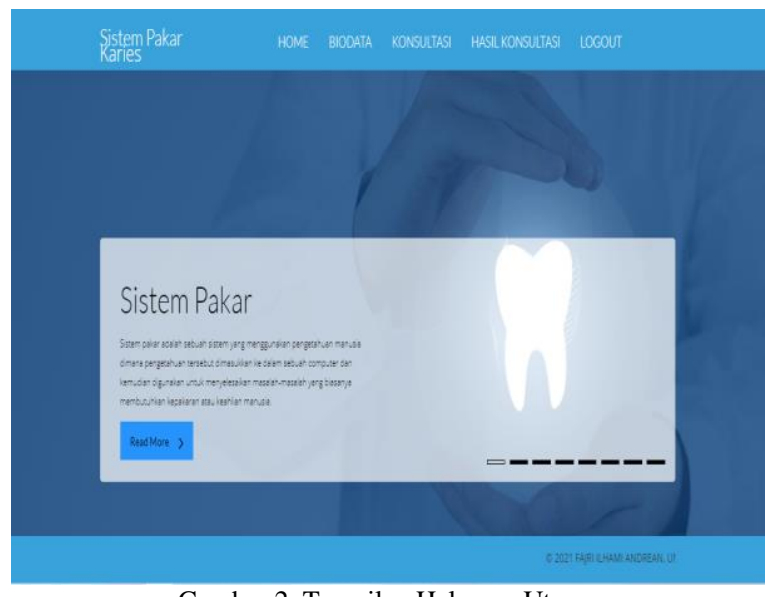

Gambar 2. Tampilan Halaman Utama

Sistem Pakar dibuat dengan user friendly dimana agar user tidak kesulitan dalam mengoperasikan sistem ini. User hanya perlu melakukan registrasi untuk dapat mengakses halaman konsultasi. Halaman konsultasi sistem disajikan pada Gambar 3:

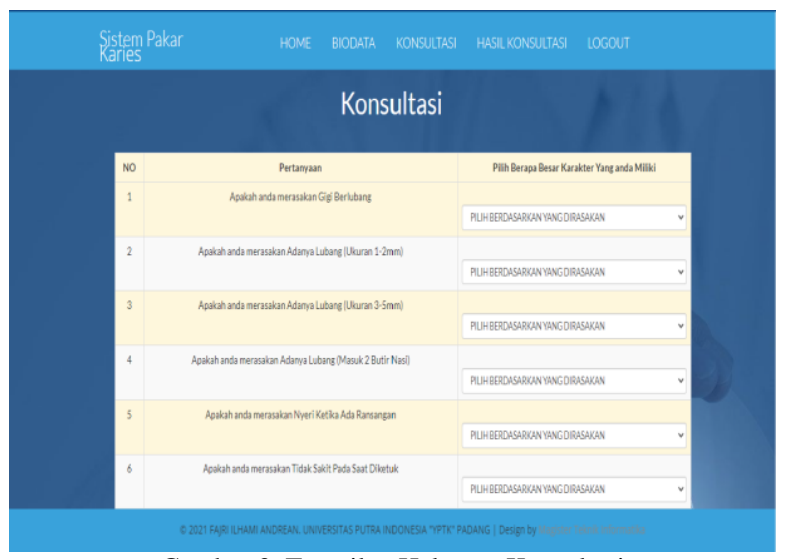

Gambar 3. Tampilan Halaman Konsultasi

Pada halaman konsultasi yang dilakukan user hanya memilih beberapa gejala yang dirasakan oleh user, saat sudah selesai melakukan pemilihan gejala user bisa lansung menekan tombol periksa konsultasi. Sistem akan memunculkan hasil diagnosa berdasarkan kepada gejala yang telah dipilih oleh user. Tampilan hasil konsultasi disajikan pada Gambar 4:

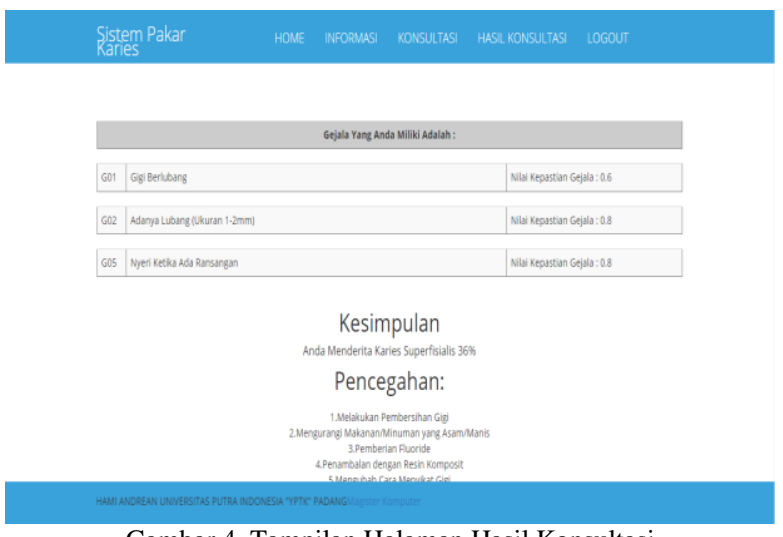

Gambar 4. Tampilan Halaman Hasil Konsultasi

Pada hasil konsultasi dapat dilihat bahwa user telah dapat mengoperasikan program dengan memasukkan gejala dan mendapatkan hasil diagnose yakni pasien terdiagnosa penyakit karies superfisialis dengan tingkat kenyakinan sebesar $36 \%$.

\section{Kesimpulan}

Sistem pakar dalam menganalisis penyakit karies gigi pada manusia berhasil diimplementasikan dengan telah dilakukannya pengujian terhadap 14 gejala dan 3 jenis penyakit karies gigi. Pengujian validasi sistem pun telah dilakukan dengan menggunakan 50 data sebagai sampel untuk pengujian dengan didapatkan hasil tingkat akurasi sebesar $94 \%$.

\section{Daftar Rujukan}

[1] Arfajsyah, H. S., Permana, I., \& Salisah, F. N. (2018). Sistem Pakar Berbasis Android Untuk Diagnosa Penyakit Gigi Dan Mulut. Jurnal Ilmiah Rekayasa dan Manajemen Sistem Informasi, 4(2), 110-117. DOI: http://dx.doi.org/10.24014/rmsi.v4i2.5678

[2] Andesti, C. L., Sumijan, \& Nurcahyo, G. W. (2020). Sistem Pakar Menggunakan Metode Certainty Factor dalam Akurasi Mengidentifikasi Penyakit Gingivitis pada Manusia. Jurnal $\begin{array}{llll}\text { Informasi dan Teknologi, 2(3), 97-104. DOI: } & \text {. }\end{array}$ https://doi.org/10.37034/jidt.v2i3.69

[3] Saputri, A. E., Sevani, N., Saputra, F., \& Sali, R. K. (2020). Using Certainty Factor Method to Handle Uncertain Condition in Hepatitis Diagnosis. Comtech (Computer, Mathematics and Engineering Applications), 11(1), 1-10. DOI: 10.21512/comtech.v11i1.5903

[4] Fauzi, M. (2018). Sistem Pakar Mendeteksi Kerusakan Keyboard Menggunakan Metode Forward Chaining. JSIK (Jurnal Sistem Informasi Kaputama), 2(1), 96-100.

[5] Santi, I. H., \& Andari, B. (2019). Sistem Pakar Untuk Mengidentifikasi Jenis Kulit Wajah dengan Metode Certainty Factor. INTENSIF: Jurnal Ilmiah Penelitian dan Penerapan Teknologi Sistem Informasi, 3(2), 159-177. DOI: https://doi.org/10.29407/intensif.v3i2.12792

[6] Syawitri, A., Defit, S., \& Nurcahyo, G. W. (2018). Diagnosis Penyakit Gigi dan Mulut Dengan Metode Forward Chaining. Jurnal Sains dan Teknologi Industri, 16(1), 24-29. DOI: http://dx.doi.org/10.24014/sitekin.v16i1.6733 
[7] Tugiono, Hafizah, Azlan, \& Milala, J. S. (2021). Sistem Pakar Untuk Pendiagnosaan Karies Gigi Menggunakan Teorema Bayes. J-SISKO TECH (Jurnal Teknologi Sistem Informasi dan Sistem Komputer TGD), 4(1), 103-111.

[8] Yansyah, I. R., \& Sumijan. (2021). Sistem Pakar Metode Forward Chaining untuk mengukur keparahan Penyakit Gigi Dan Mulut. Jurnal Sistim Informasi dan Teknologi, 3(2), 41-47. DOI: https://doi.org/10.37034/jsisfotek.v3i2.103

[9] Arysespajayadi, Sutoyo, M. N., \& Qammadin. (2019). Implementasi Metode Certainty Factor pada Sistem Pakar Diagnosa Penyakit Karies Gigi. Jurnal Sains dan Informatika, $5(2)$, $167-176$

DOI: https://doi.org/10.34128/jsi.v5i2.188

[10] Andriani, A., Meyliana, A., \& Susanto, W. E. (2018, August). Certainty Factors in Expert System to Diagnose Disease of Chili
Plants. In 2018 6th International Conference on Cyber and IT Service Management (CITSM) (pp. 1-6). IEEE. DOI: https://doi.org/ 10.1109/CITSM.2018.8674264

[11]Aeni, K. (2018). Penerapan Metode Forward Chaining Pada Sistem Pakar Untuk Diagnosa Hama dan Penyakit Padi. INTENSIF: Jurnal Ilmiah Penelitian dan Penerapan Teknologi $\begin{array}{llll}\text { Sistem } & \text { Informasi, } & \text { 2(1), }\end{array}$ 10.29407/intensif.v2i1.11841

[12] Widians, J. A., Puspitasari, N., \& Ameilia, U. (2018). Expert System of Black Orchid Cultivation using Certainty Factor Method. In 2018 2nd East Indonesia Conference on Computer and Information Technology (EIConCIT) (pp. 35-40). IEEE. DOI: 10.1109/EIConCIT.2018.8878534 